\title{
18
}

\section{THE TORONTO PUBLIC LIBRARY AS A SITE OF URBAN CARE, SOCIAL REPAIR, AND MAINTENANCE IN THE SMART CITY}

\author{
Teresa Abbruzzese and Antony Riley
}

\section{Introduction}

Like many public institutions throughout urban North America, public libraries have undergone remarkable transformations in the last several decades (Klinenberg 2018; Leckie and Hopkins 2002; Mattern 2014, 2018). At the Toronto Public Library (TPL) in Toronto, Canadathe case study for this chapter-not only can library users borrow traditional materials such as books, films, and reference works; they can also receive free job search, career, and financial advice; find out how to self-publish their own written materials; attend open microphone nights, literary talks, and documentary screenings; learn yoga and meditation; join book clubs and writers' groups; access Wi-Fi and borrow computers, digital printers, and 3D printers; and take classes in web design and coding. There are also a host of programs, services, and resources available for more specialized groups, such as children and teens, non-English-speaking newcomers to Canada, people with disabilities, and people experiencing difficulties with poverty and homelessness. In response to the needs of some members of these latter populations, the TPL now provides staff training in social work approaches and has recently hired its own inhouse social worker.

Similar trends can be found at public libraries in cities across the continent. Taken together, and on the surface, they speak to current conceptions of the urban public library as an indisputable site of urban care, a clear example of a democratic and compassionate public institution serving the public good. The 'public' in this context is understood in its broadest terms to include society's most vulnerable groups. But as we aim to show in this chapter, on closer inspection there has been a more complex and contradictory side to some of these developments. Library programs, resources, and services, along with newly conceived structures and functions associated with promoting advanced technology and 'big' business interests, in particular, have raised concerns in Toronto as elsewhere that libraries are drifting too far away from their traditional social and educational mandate-what Eric Klinenberg (2018) refers to as 'social infrastructure.' In the smart city, libraries are mere 'innovation hubs,' 'entrepreneurial incubators,' and 'digital agents' serving a largely uncaring, neoliberal, techno-urban agenda (Leorke et al. 2018; Mattern 2014). 
Our chapter examines the dynamics of one version of this controversy as played out recently in the context of Toronto's 'smart city' planning conversations under Mayor John Tory (still the incumbent as of this writing). We focus in particular on a number of the debates that arose during the 2010s among city officials, politicians, library administration, and Toronto Region Board of Trade (TRBOT) members as they sought to reposition the TPL and bring it more in line technologically and financially with city authorities' smart city vision. Notably, that vision was at one point to have included a section of Toronto's waterfront developed by Sidewalk Labs - an urban tech affiliate of Google's parent company, Alphabet. In 2017, Waterfront Toronto (formerly the Toronto Waterfront Revitalization Corporation) launched a public request for a proposal to solicit submissions for the development of an underdeveloped eastern portion of Toronto's industrial waterfront and chose Sidewalk Labs as the winner.

Although Sidewalk Toronto ultimately failed to materialize, the events that unfolded surrounding this controversial development have considerable implications for libraries in other urban centers where similar smart city initiatives are underway. We argue that libraries are key sites of social repair and maintenance in building an inclusionary smart city, and as Dale Leorke, Danielle Wyatt, Scott McQuire (2018) and others have shown in their studies on libraries in smart cities, they are integral digital agents in facilitating the 'smart citizenry' for this technocratic urban model. While digital literacy seems a 'natural' expansion of libraries' educational responsibilities in the data-driven economy of the twenty-first century, maintaining the library as a social infrastructure seems more threatened under neoliberal conditions. Unpacking the role of libraries in smart city discussions and initiatives as 'enablers' and 'leaders' in the digital economy, and shedding light on how librarians navigate tensions between digital and social repair mandates are the objectives of this chapter. We argue that public libraries are contradictory sites of urban care that mediate and mobilize the technocratic logic of the smart city.

The chapter has two main sections. In the first, we present theoretical conceptualizations of the smart city, of a feminist ethic of care, and of the politics of urban social repair and maintenance to highlight how libraries are redefining their social responsibilities to align more closely with mandates of the neoliberal smart city. In the second, we flesh out these concepts with a selection of interview excerpts and other observations drawn from our empirical research. In the process, we raise new questions on libraries as critical spaces of social infrastructure under neoliberal conditions. ${ }^{1}$

\section{The Smart City: Merging Technology, Entrepreneurialism, and Libraries}

The critical literature surrounding the proliferation of smart cities is greatly concerned with definitions of the new urban form, encompassing issues of privacy, exclusion, and the neoliberalization of urban planning and design. However, Giuseppe Grossi and Daniela Pianezzi's (2017) assertion that a common definition of a smart city does not exist still remains true. Alongside some of the definitions on offer are claims that the adoption of comprehensive smart city infrastructure is technical, neutral, and apolitical in nature (Kitchin 2015). Despite these claims, there is a growing body of literature that focuses on the political natureparticularly the neoliberal underpinnings — of this digital city model and questions of local urban governance based upon privatization, public-private partnerships, the exposure of 
municipalities to global competition, and the mobilization of an entrepreneurial ethos and discourse (Grossi and Pianezzi 2017).

Within the context of urban entrepreneurialism, public libraries have become key facilitators and, by extension, digital agents in the smart city as collaborators and co-creators with public and private agencies. The transition to entrepreneurial urban governance is reflected in the library's changing role as a publicly funded agency mandated to reprioritize services and collections around the market needs of the neoliberal economy in order to justify its relevance (Leorke et al. 2018; McMenemy 2009). Under this new corporate/management model of service, patrons become clients, programs become services, and libraries compete for funding (with online retail and book stores as well as other public institutions) to 'enhance' services and remain 'competitive' (Stevenson 2009). Concomitant with the resultant funding shortages are cuts in services and staff (McMenemy 2009). As John Buschman (2004: 42) states, "the democratic public and social function of libraries subtly but surely changes: From a space for research, reflection and reading to the social capital of a community." Thus, he argues, with the increasing prioritization of funding, customer service, and social innovation comes the dismantling of libraries' core democratic values.

\section{A Feminist Ethic of Care: Libraries as Caring Institutions}

A feminist ethic of care (England 2010) extends questions of care from the private sphere of the home and family to the public sphere, focusing, more broadly, on the many other care relations that enhance the well-being of societies. Following in this vein, Berenice Fisher and Joan Tronto (1990: 40, original emphasis) define care as a "species activity that includes everything that we do to maintain, continue, and repair our 'world' so that we can live in it as well as possible." Their conceptualization emphasizes care as not only a practice, but also as a political value that transcends the private realm of the household and occurs in a variety of institutions and settings.

Examining institutions such as libraries through a feminist ethic of care lens challenges the techno-driven solutions of the smart city by emphasizing human interdependence, and reveals libraries as spaces of urban care. Such an ethical perspective also moves theoretical discussions on gendered aspects of care from a narrow focus on who provides the care and the experience of caregiving to everyday life, including everyday life as experienced in public institutions.

As we have described it so far, the feminist ethic of care, while a challenge to many aspects of the smart city project, does not necessarily encourage an outright rejection of the smart city. It is still possible within the critiques the feminist ethic of care offers to uphold a smart city vision, albeit one transformed to better welcome and support the kinds of caring and community concerns that institutions such as public libraries can provide.

\section{Social Repair and Maintenance: Are Libraries Broken?}

When we think of repair and maintenance in cities or enterprises, we usually think of hard infrastructure, i.e., the physical and organizational structures and facilities needed for their operation. Such infrastructure is, as Susan Leigh Star (1999) points out, crucial, but it is mostly hidden and embedded in structures, technologies, and social arrangements. It only becomes visible when it breaks down. Stephen Graham and Nigel Thrift's (2007) work on repair and maintenance in cities exposes how cities' hard infrastructures are continually breaking down 
and being 'fixed' through mundane, piecemeal activities of upkeep and repair that reflect the improvisational resilience of their respective citizenries and governments. Thrift's (2005) earlier work on the micro-politics of care and welfare, however, focuses specifically on the politics of 'social' repair and maintenance in cities and how acts and practices of kindness and compassion can improve everyday life for even the most vulnerable city populations, thus fostering a collective urban politics of hope.

These social elements form part of what Klinenberg (2018) refers to as 'social infrastructure.' As he demonstrates, social infrastructure can be found in almost any public institution or commercial establishment where people congregate and socialize, where conversations and human contact happens. Not only does social infrastructure nurture and protect democracy, it also contributes to economic growth and well-being. Notably, libraries are among the public institutions Klinenberg highlights.

The library's particular social infrastructure, with its connections to community functions of care and education, makes it arguably one of the most critical public institutions in cities. However, like many other institutions in North America, Europe, the United Kingdom, and Australia operating under conditions of urban austerity, the library is increasingly facing contradictory tensions as its public mandate is challenged by broader neoliberal shifts. Shannon Mattern (2014) makes the case that libraries are sites of intersecting 'infrastructural ecologies' and despite functioning under the chronic threat of budget cuts, underfunding, and closures, they continue to be important social anchors in communities. Mattern (ibid.) argues not only have libraries had to 'pick up' social responsibilities as a result of declining state provision of social services, they have also had to align their mandate closely around the neoliberal rhetoric of innovation, digital literacy, and entrepreneurialism. Such tensions raise epistemological questions on how competing infrastructures maintain or weaken libraries' longstanding cultural values and democratic commitment to knowledge production and sharing. The work of Leorke, Wyatt, and McQuire (2018) on a public library development in Geelong, Australia, as part of a broader digital transition from a post-industrial economy to a knowledge economy, highlights libraries' complex entanglements with government and digital city building projects that articulate the contradictory tensions of this public institution in serving competing publics and needs. In her study on the TPL as a critical public space for social reproduction, Lia Frederiksen (2015: 150) argues that the "proliferation of philanthropic gifts and corporate donations to fund library programs has also been criticized by library proponents for introducing corporate influence into libraries [...]. They contend that these strategies introduce more explicit market logic into public libraries." Under such conditions, the public library is becoming fragile. The question is:Will it break? Are there sufficient social infrastructural repair and maintenance mechanisms in place to prevent that from happening? The empirical section below suggests some possible answers.

\section{The Toronto Public Library Case: Struggles for Urban Care, Repair, and Maintenance in the Smart City}

Before launching into our empirical part of the chapter, it is important to first provide a few further details about Toronto as a smart city and about the TPL.

\section{Toronto as a Smart City}

During the transition years from the twentieth to the twenty-first century, Toronto, like many cities around the world caught up in both the cultural rhetoric and competitive economic 
imperatives of 'globalization,' sought to establish a position for itself on the global stage as a 'global' or 'world-class' city. However, with the rapid proliferation of 'smart,' digital technologies and the further entrenchment of the global, neoliberal turn in the early 2000s, Toronto, again like many of its counterpart urban centers, began to seek a somewhat different identification, and thus a greater competitive advantage, as a smart city.

As already suggested above, there are multiple definitions of the term 'smart city', and it is not our purpose here to wade through them all. However, if we take even the most basic definition, i.e., an urban development vision of a data-driven economy that integrates information and communications technology (ICT) to (ostensibly) improve quality of life, address urban and environmental challenges, and increase economic competitiveness, it can probably be said that the term smart city gained serious traction in Toronto with the election of Mayor John Tory in 2014. Under Tory, a neoliberal smart city vision for Toronto emerged, replete with digital, entrepreneurial, and public-private partnership initiatives designed to push the city further into the twenty-first century and make it more economically competitive globally.

In February 2016, the TRBOT, along with member stakeholders, formed a Smart Cities Working Group (SCWG) with City of Toronto administrators to collaborate on building and implementing a smart city vision for the city. This working group organized three annual Smart City Summits to raise awareness and engage dialogue across the Toronto region, and helped facilitate citizen engagement and feedback segments for the Canadian Federal Government's Smart City Challenge (2017/2018). For this competition, cities and communities across Canada submitted proposals showcasing their smart cities approach to improving the lives of residents in the hopes of winning four financial awards ranging from $\$ 5$ million to $\$ 50$ million. The SCWG was tasked with providing a roadmap that highlighted Toronto's local smart innovations along with international best practices; creating a 'smart' case studies inventory of the region; and supporting the pan-Canadian Smart Cities Challenge by facilitating discussions with stakeholder members in various TPL branches and community centers.

One key, yet highly controversial, initiative in this vision was the Toronto project (see Figure 18.1). This high-profile real estate deal garnered global attention because this would have been the first time a tech giant was hired as a master developer to build what chief executive officer of Sidewalk Labs Daniel Doctoroff (2016) envisions a neighborhood "from the internet up." It was seen as Sidewalk Labs' opportunity to realize their 'technotopia,' experimenting with their different products, technologies, and services. The high-tech, sensor-andsurveillance-laden neighborhood was intended to include free Wi-Fi, self-driving cars, heated and illuminated sidewalks controlled by sensors, affordable housing, tall timber structures, and other initiatives to support environmental sustainability (see Figure 18.2).

In 2019, the TPL became a potential key player in Sidewalk Toronto's plans with the TRBOT's recommendation to make the TPL a civic data trust for the Quayside development. In response to the heightened negative attention the project was receiving regarding data governance and intellectual property rights, the board, whose mission it is to attract investment to make Toronto one of the most competitive and coveted business regions in the world, proposed the TPL as a 'neutral' independent data trust. This recommendation was not given much attention in public debates, as initial reactions to the report recognized the limitations of the library as a data trust managing the collection and use of data. Due to economic uncertainties tied to COVID-19, and to growing concerns over the privacy rights and related implications of its extensive surveillance infrastructure, the Sidewalk Toronto project was 


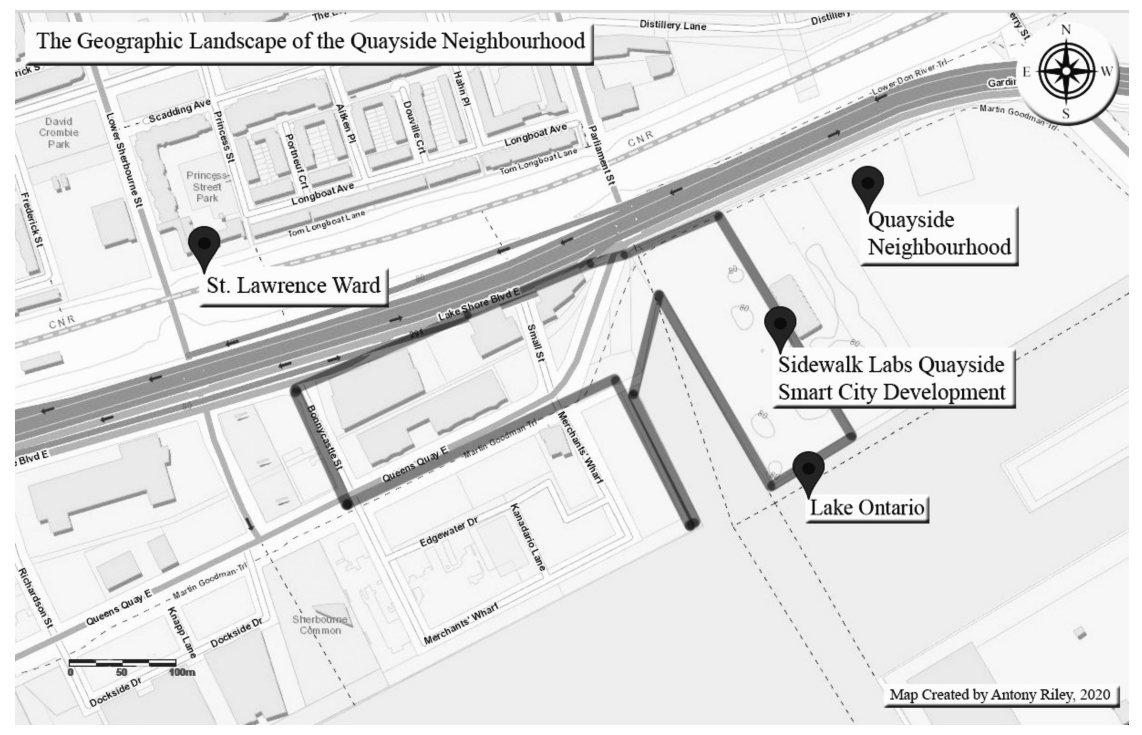

FIGURE 18.1 Quayside Neighborhood, Toronto’s Eastern Waterfront. Source: Antony Riley, 2020.

cancelled in May 2020. As we will show in the remainder of this chapter, however, the TPL was to play no small part in the critical discourse that emerged.

\section{The Toronto Public Library}

According to its website, the TPL (2020) is "one of the world's busiest library systems." There are currently 100 local branches serving neighborhoods in the downtown urban core as well as throughout the suburbs. The centerpiece building is the Toronto Reference Library (TRF), opened in 1977 and situated near the city's main intersection of Yonge and Bloor Streets. The reference library is considered an important city landmark and an architectural gem (see Figure 18.3).

At the 2018 Toronto International Film Festival (TIFF), the TRF was chosen as a location for a private screening of Emilio Estevez's film The Public for TPL foundation donors. The film is about a group of homeless individuals in Cincinnati who barricade themselves in a public library during a harsh Midwestern cold snap. The role of librarians in the film transitions from negotiators to social activists as the civil protest escalates to a confrontation with local police. Estevez premiered the film at the TPL to bring attention to the plight of homeless groups and to drive home his message that libraries as one of the few remaining 'public' institutions in modern cities need to continue to be sites of compassion and care.

At the screening, Vickery Bowles, the TPL's Chief Librarian, introduced the film, explaining how the library is a place of refuge for vulnerable and marginalized persons and highlighting some of the strategies the TPL has implemented to help them, such as branches serving as emergency warming and cooling centers; book mobiles and community librarians working with agencies and city shelters; and hiring a social worker on staff. Indeed, the library in this context was celebrated as an invaluable public space offering a safe space to the public free of charge (TPL Foundation 2018). 


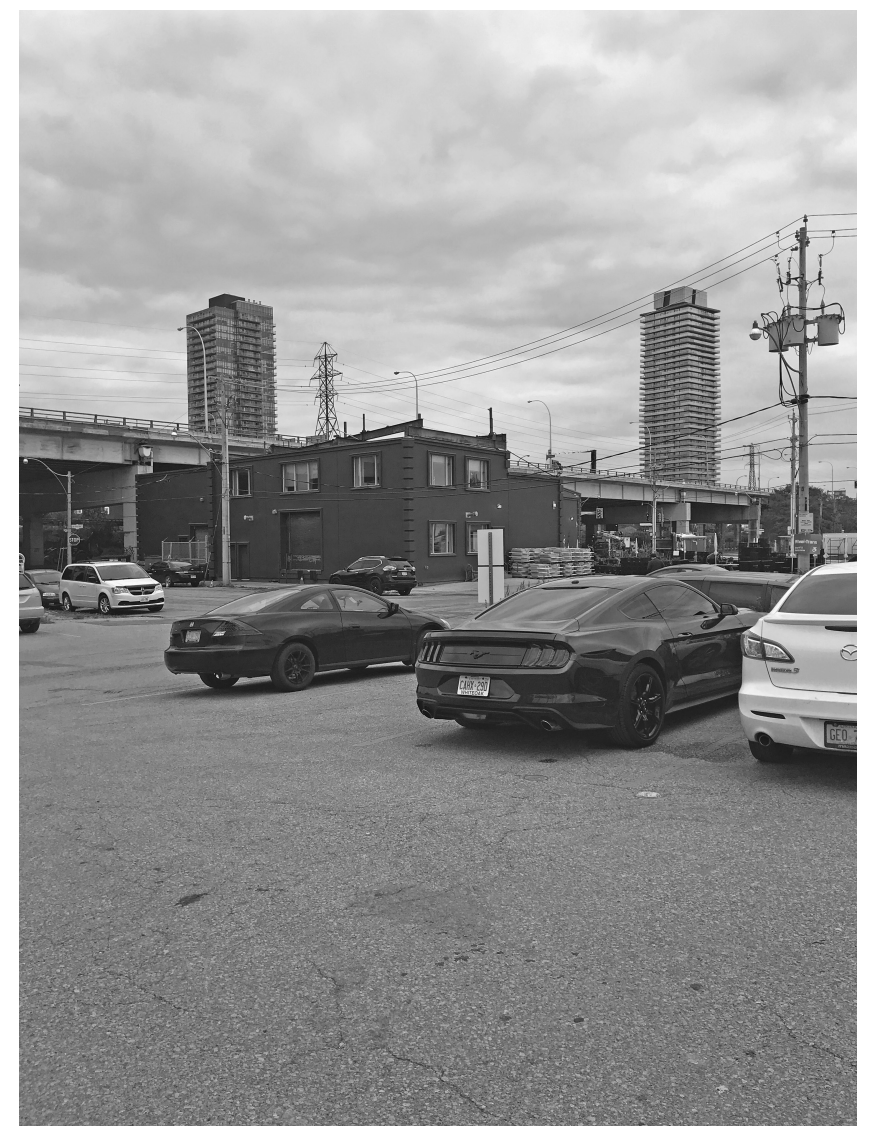

FIGURE 18.2 Sidewalk Labs 307, a former industrial building converted to an experimental hub and office space. Source: Teresa Abbruzzese, 2018.

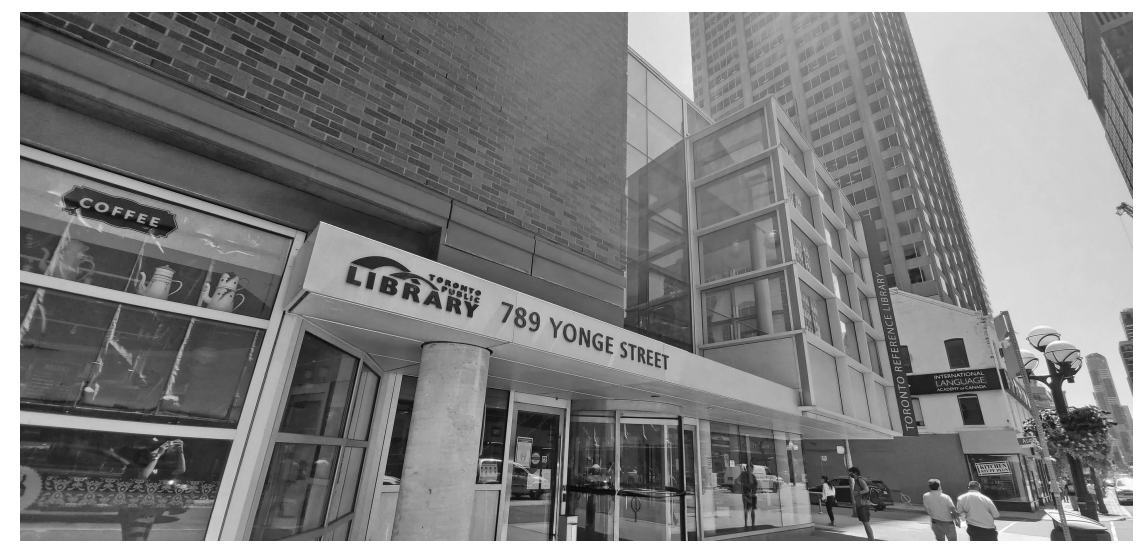

FIGURE 18.3 Toronto Public Library. Source: Antony Riley, 2020. 
In her many public engagements discussing the role of the TPL in the smart city, Bowles (2018) always reinforces the point that "they are busier than ever because the customers expect more." Another communitarian image Bowles employs when discussing issues of inclusion is how the "public library is the people's university" (ibid.). Thus, discourses of inclusion in the techno-urban imaginary of the smart city are co-opted as discursive strategies for the TPL to maintain continued public and donor funding, and to justify their program partnerships with tech giants such as Cisco and Google.

As places of knowledge sharing, libraries have become key symbolic spaces with discursive power in the broader digital-divide discourse as they provide education, training, and access to digital technologies. Quoting Bill Gates, Siobhan Stevenson (2009) argues that the discursive strategy to naturally align libraries with digital industries in helping bridge the digital divide is a neoliberal strategy to further enmesh the state in the globalized information economy. This echoes the perspective of this TPL librarian (personal communication, March 2019):

When people think about smart cities, they think tech and data and they don't think about the human aspect, the social. They think more about the economic aspect than the social. There is a digital divide where people don't have the access, opportunity or connections to reach their potential. So what the public library does is provide equitable access to not just everyday tech, but also emerging tech and we think that's an important role for the public library.

Within this broader conversation on digital access and equity is growing attention on the public library as a key democratic space, which also yields symbolic and discursive significance in related conversations on trusted spaces in civil society. However, the contradictory relationship between a 'benevolent' public institution free of commercial interests and an urban model driven by private interests reveals tensions as libraries become more recognized as entrepreneurial agencies.

Thrift's (2005) conceptualizations on processes of social repair and maintenance help us understand the integral role of the public library in Toronto's smart city. At the time of heightened public scrutiny and questioning around Sidewalk Toronto, the TRBOT recommended in their report that responsibility and authority for developing a civic data hub and its related policies be assigned to the TPL (Ruttan et al. 2019). The report argues that the TPL has the resources, expertise in data maintenance, and most importantly public trust to shape a data governance model maintaining public control. The library, in this moment of growing public anxiety and resistance to the Sidewalk Toronto proposal, was seen as the trusted channel to democratize the digital layer, as articulated by TRBOT members (personal communication, March 2019):

We chose the library because it was a respected and a well-known body that is perceived to uphold the public interest, which we saw as a crucial component to help bring in the right players to have those discussions on financing and data handling. It's not just about libraries increasing relevancy in a digital world but it would be about the democratization of that digital world. The process would be a foundational building block in ensuring the protection of the public interest. 
This recommendation received many criticisms for extending the public reach of the library as a data trust. As one city official (personal communication, March 2019) noted: "I think it runs the risk of asking the library to overstep because their branding implies trust, but it's a stretch to say they can handle data analytics. I don't think it's their function to control city data."

As one of the remaining 'public' institutions in modern cities, there is a need to bring a critical caution to conversations on the mobilization of libraries in smart cities as trusted sites of access and inclusion.

Reprioritizing programs under neoliberal conditions to produce the smart citizens needed for the data-driven economy has been integral to public libraries' funding, which has generally declined in Canada, the US, the United Kingdom, and Australia (Leorke et al. 2018). As we learned during our case study, funding for the TPL has been prioritized in recent years because librarians have adopted the language and entrepreneurial discourse that emphasizes exchange value and understand how addressing social needs and disparities in neighborhoods can generate economic benefits in the overall economy. According to a TPL librarian (personal communication, March 2019), funding is related to reallocating resources and prioritizing certain services, which she argues does not undermine the core values of the institution.

We did get some enhanced funding for Wi-Fi hotspot lending, so people can borrow them the way they do for books [...]. We reallocated resources to support our strategic plan: a new digital strategy, new training and programming to support staff in understanding how their role is changing. But I want to say our values have not changed, they've been the same, such as literacy, equitable access to diversity of information and ideas, intellectual freedom, protection of privacy, lifelong learning.

While libraries are operationalizing their mandate and services increasingly through an entrepreneurial approach to social provision, the everyday practices of care guided by the public institution's core values shed light on a feminist, place-based, or urban ethic of care.

Our study reveals the heightened social obligations libraries are currently experiencing as public institutions under neoliberal conditions. The notion of librarians as 'first responders' also emphasizes the library as a social agency with an urban ethic of care. As this TPL librarian (ibid.) explains:

I think we're operating in an urban environment where we end up being first responders like anyone in the public sector who works with the public. There are income gaps and social issues, such as the opioid crisis and because we're a public institution, people can just walk in and we welcome them. We need to respond to those situations, and it has been very difficult for the staff without the expertise of a social worker to provide guidance and training and ideas for how to manage those kinds of situations. We're trying to continue to ensure our libraries provide a welcoming and supportive environment so that everyone is welcome and able to participate in whatever way they see fit.

In their justification, this librarian sees an intrinsic connection between public sector work, care, and social repair. 


\section{Conclusion}

Once regarded primarily as public institutions of education and care, libraries are today redefining their roles to assume new, additional status as digital leaders, enablers, and city builders. Our case study on the role of the TPL in the development of Toronto's smart city vision highlights some of the specific ways libraries are becoming more entrenched with neoliberal smart city agendas, not only as providers of digital services and free information, but as key stakeholders in information- and data-driven economies.

While Toronto is focusing on digital repair to improve its service efficiency, as well as on social and environmental sustainability in selling the idea of a more economically competitive city region to invest and live in, we claim that public libraries are not broken; rather, they are key spaces that will provide needed social repair and maintenance to facilitate the smart city through digital literacy and by providing users access to technology, space, and resources. The entrepreneurialization of the library, we argue, destabilizes the role of the library in the community as a space of care and social repair; however, it does not completely erase it.

\section{Note}

1 This investigation is part of a broader study on the role of public libraries in the smart city which included discourse analysis of extensive literature and media scans, as well as semi-structured interviews conducted in 2019 with a TPL librarian, a public official and senior economic development officer at the City of Toronto, and members of the TRBOT. These interviews were triangulated with notes between 2017 and 2019 from meetings Teresa Abbruzzese attended as an academic member of the TRBOT Smart Cities Working Group, visits to the Sidewalk Labs' 307 experimental workspace, and ideation sessions with the Chief Transformation Officer in preparation for Toronto's bid for the Canadian government's Smart City Challenge in 2017.

\section{References}

Bowles, V. (2018) Collaboration, Innovation, Inclusion: Smart Cities. Presentation at the IoT Events: Annual Intelligent Cities Summit. Beanfield Centre, Toronto, 9 November.

Buschman, J. (2004) Staying Public: The Real Crisis in Librarianship. American Libraries 35(7): 40-44.

Doctoroff, D. (2016) Reimagining Cities from the Internet Up. Sidewalk Labs [Online]. Available at https://www.sidewalklabs.com/blog/reimagining-cities-from-the-internet-up/ [Accessed 20 November 2020].

England, K. (2010) Home, Work and the Shifting Geographies of Care. Ethics, Place and Environment 13(2): 131-150.

Fisher, B. and Tronto, J.C. (1990) Toward a Feminist Theory of Caring. In E.K. Abel and M.K. Nelson (eds.) Circles of Care:Work and Identity in Women's Lives. Albany: State University of New York Press, pp. 36-54.

Frederiksen, L. (2015) 'Our Public Library': Social Reproduction and Urban Public Space. Women's Studies International Forum 48(15): 141-153.

Graham, S. and Thrift, N. (2007) Out of Order: Understanding Repair and Maintenance. Theory, Culture E Society 24(1): 1-25.

Grossi, G. and Pianezzi, D. (2017) Smart Cities: Utopia or Neoliberal Ideology? Cities 69(9): 79-85.

Kitchin, R. (2015) Making Sense of Smart Cities: Addressing Present Shortcomings. Cambridge Journal of Regions, Economy and Society 8(1): 131-136.

Klinenberg, E. (2018) Palaces for the People: How Social Infrastructure Can Help Fight Inequality, Polarization, and the Decline of Civic Life. New York: Crown. 
Leckie, G.J. and Hopkins, J. (2002) The Public Space of Central Libraries: Findings from Toronto and Vancouver. The Library Quarterly: Information, Community, Policy 72(3): 326-372.

Leigh Star, S. (1999) The Ethnography of Infrastructure. American Behavioral Scientist 43(3): 377-391.

Leorke, D., Wyatt, D. and McQuire, S. (2018) "More than Just a Library": Public Libraries in the "Smart City'. City, Culture and Society 15(5):37-44.

Mattern, S. (2014) Library as Infrastructure. Places Journal, June. https://doi.org/10.22269/140609.

Mattern, S. (2018) Maintenance and Care. Places Journal, November. https://doi.org/10.22269/181120.

McMenemy, D. (2009) Rise and Demise of Neoliberalism: Time to Reassess the Impact on Public Libraries. Library Review 58(6): 400-404.

Ruttan, C., Chakarova, R., Apollonova, N., Gill, P., Kelcey, B. and Simovic,V. (2019) Biblio Tech, Beyond Quayside: A City-Building Proposal for the Toronto Public Library to Establish a Civic Data Hub [Online]. Toronto Region Board of Trade. Available at https://www.bot.com/Portals/0/Bibliotech \%20-\%20Final\%20-\%20Jan\%208.pdf?timestamp=1546987861621 [Accessed 5 August 2020].

Stevenson, S. (2009) Digital Divide: A Discursive Move Away from the Real Inequities. Library Review 57(4): $1-22$.

The Public (2019) Directed by E. Estevez [Film]. USA: Universal.

Thrift, N. (2005) But Malice Aforethought: Cities and the Natural History of Hatred. Transactions of the Institute of British Geographers 30(2): 133-150.

Toronto Public Library (TPL) (2020) About the Library [Online]. Available at https://www.torontop ubliclibrary.ca/about-the-library/ [Accessed 20 November 2020].

Toronto Public Library Foundation (2018) An Interview with Emilio Estevez at Toronto Public Library [Video]. Available at https://www.youtube.com/watch?v=WR8Oz8jawdY [Accessed 5 August 2020]. 